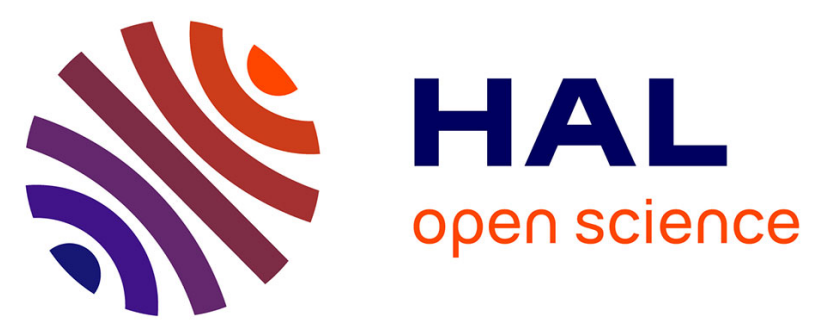

\title{
The contribution that the concept of global public goods can make to the conservation of marine resources
}

\author{
Sandrine Maljean-Dubois, Carina Costa de Oliveira
}

\section{To cite this version:}

Sandrine Maljean-Dubois, Carina Costa de Oliveira. The contribution that the concept of global public goods can make to the conservation of marine resources. Ed Couzens, Alexander Paterson, Sophie Riley, Yanti Fristikawati,. Protecting Forest and Marine Biodiversity: The Role of Law, Edward Elgar Publishing, pp.290-314, 2017, The IUCN Academy of Environmental Law Series, 978-1-78643-948-2. halshs-01675496

\section{HAL Id: halshs-01675496 \\ https://shs.hal.science/halshs-01675496}

Submitted on 19 Apr 2018

HAL is a multi-disciplinary open access archive for the deposit and dissemination of scientific research documents, whether they are published or not. The documents may come from teaching and research institutions in France or abroad, or from public or private research centers.
L'archive ouverte pluridisciplinaire $\mathbf{H A L}$, est destinée au dépôt et à la diffusion de documents scientifiques de niveau recherche, publiés ou non, émanant des établissements d'enseignement et de recherche français ou étrangers, des laboratoires publics ou privés. 


\title{
12. The contribution that the concept of global public goods can make to the conservation of marine resources
}

\author{
Carina Costa de Oliveira and Sandrine \\ Maljean-Dubois*
}

\section{INTRODUCTION}

Vague and imprecise concepts hinder progress towards defining and implementing international obligations for the conservation of the marine environment. While concepts such as global public good, common heritage of humankind and global commons are frequently used to discuss the governance of marine resources, particularly in areas beyond national jurisdiction, they are too often disconnected from any norms that might effectively link them to implementation and enforcement. The debate on the tragedy of the commons ${ }^{1}$ is indeed still relevant today, especially in light of statistics revealing increasing over-exploitation of marine resources on the high seas ${ }^{2}$ and the unbridled quest to exploit resources in such inhospitable places as the Arctic and Antarctica. ${ }^{3}$ It is therefore

* A similar article was published in Portuguese in the Brazilian Journal of International Law. Carina Costa de Oliveira and Sandrine Maljean-Dubois, 'Os limites dos termos bem público mundial, patrimônio comum da humanidade e bens comuns para delimitar as obrigações de preservação dos recursos marinhos' (2015) 12 Revista de Direito Internacional 109-124. Permission granted for substantial re-use.

1 For more on this subject, see Elinor Ostrom, Governing the Commons, the Evolution of Institutions for Collective Actions (Cambridge University Press, 1990); Michael A. Heller, 'The Tragedy of the Anticommons, Property in the Transition from Marx to Markets' (1998) 111 Harvard Law Review 622; Catherine Logeat, Les biens privés affectés à l'utilité publique (L'Harmattan, 2011); Beatrice Parance and Jacques de Saint Victor, Repenser les communs (CNRS Ed., 2014).

2 For more on this subject, see, for example, the statistics compiled by the FAO about deep-sea fishing. FAO, Yearbook of Fishery and Aquaculture Statistics (2014) http://www.fao.org/fishery/statistics/yearbook/en (accessed 5 May 2015).

3 For more on this subject, see the following news articles: Euronews, 13 May 2016, Shell recebe luz verde para a prospeção no Ártico http://pt.euronews. 
important to present a brief overview of these different concepts and of their linkages to living and non-living marine resources, and to try to highlight their articulation (or sometimes disarticulation) with states' international obligations vis-à-vis the protection of marine resources.

\section{A BRIEF OVER VIEW OF THE CONCEPTS OF GLOBAL PUBLIC GOOD, COMMON HERITAGE OF HUMANKIND, AND GLOBAL COMMONS}

\subsection{Global Public Goods: Not a Legal but an Interpretive Value}

The terminology for global public goods is still nebulous and far from precise from a legal point of view. The term has been used and cited in legal texts in areas ranging from health ${ }^{4}$ to the environment (and in particular the marine environment), ${ }^{5}$ commerce $^{6}$ and information

com/2015/05/13/shell-recebe-luz-verde-para-a-prospecao-no-artico/ (accessed 13 May 2016); 'Grabbing Paddles in Seattle to Ward off an Oil Giant', The New York Times, 12 May 2015, http://www.nytimes.com/2015/05/12/us/grabbing-paddles-inseattle-to-ward-off-an-oil-giant.html?_r=5 (accessed 20 May 2015). For analysis of statistics for the Antarctic see: CCAMLR Statistical Bulletin (Vol. 25, 2000) https://www.ccamlr.org/en/document/publications/ccamlr-statistical-bulletinvol-25 (accessed 15 June 2015). See also Keith Reid, 'Conserving Antarctica from the Bottom Up, Implementing UN General Assembly Resolution 61/105 in the Commission for the Conservation of Antarctic Marine Living Resources (CCAMLR)' (2011) 25 Ocean Yearbook 131; Christopher R Rossi, 'A Particular Kind of the Grotian Tendency and The Global Commons in a Time of High Arctic Change' (2015) 11 International Law and International Relations 1.

4 See Bruno Boidin, La santé, bien public mondial ou bien marchand, reflexions a partir des experiences africaines (Presses Universitaires du Septentrion, 2014); David Gartner, 'Global Public Goods and Global Health' (2012) 22 Duke Journal of Comparative and International Law 303.

5 See Jean-Frédéric Morin and Amandine Orsini, Essential Concepts of Global Environmental Governance (Routledge, 2015) 84, 86; Elisa Morgera, 'Bilateralism at the Service of Community Interests? Non-judicial Enforcement of Global Public Goods in the Context of Global Environmental Law' (2012) 23(3) The European Journal of International Law 748, 753; Timothy Meyer, 'Global Public Goods, Governance Risk and International Energy' (2012) 22 Duke Journal of Comparative and International Law 319; Nico Krisch, 'The Decay of Consent, International Law in an Age Of Global Public Goods' (2014) 108 The American Journal of International Law 1, 16, 21; Betty Queffelec, 'Commons' in I. Casillo with R. Barbier, L. Blondiaux L, F. Chateauraynaud, J-M. Fourniau, R. Lefebvre, C. Neveu et D. Salles (eds), Dictionnaire critique et interdisciplinaire de la participation (GIS Démocratie et Participation, 2013).

6 Robert W. Staiger, Report on the International Trade Regime for the 
services. ${ }^{7}$ With a term that has been so broadly employed, an analysis of the concept's function and content seems to be necessary.

The concept of global public good emerged from the work of several economists. ${ }^{8}$ International organizations have since contributed considerably to the debate about the term, particularly in the wake of the United Nations Development Programme's (UNDP) publication 'Global Public Goods: International Cooperation in the Twenty-First Century'. The UNDP followed up with further publications on the issue ${ }^{10}$ and other international organizations such as the World Bank also produced related documents. ${ }^{11}$ Meanwhile, several national institutions dedicated themselves to developing the concept as it related to other spheres, such as development aid. ${ }^{12}$

The concept has been used to address challenges of a global scale, with different specificities for each thematic area. ${ }^{13}$ Some legal articles approach the matter from perspectives that relate to demonstrating general institutional deficiencies in the context of public international law

International Task Force on Global Public Goods, 2006 http://www.regeringen.se/ contentassets/4e7cc9afcd2444d38d5b507bb6cf9b49/global-public-goods-interna tional-trade (accessed 10 June 2015); Petros C. Mavroidis, 'Free Lunches? WTO as Public Good, and the WTO's View of Public Goods' (2012) 23(3) The European Journal of International Law 731, 742; Fabrizio Cafaggi, 'Private Regulation and the Production of Global Public Goods and Private "Bads"' (2012) 23(3) The European Journal of International Law 695, 718; Ernst-Ulrich Petersmann, 'International Economic Law, "Public Reason" And Multilevel Governance of Interdependent Public Goods' (2011) 14 Journal of International Economic Law 23,76 .

7 See UNESCO, Speech by Koïchiro Matsuura, General Director at the time of the Sommet mondial des régulateurs sur Internet et les nouveaux services (DG/99/2/KM, 1999).

8 See the works of P. Samuelson in the 1950s. See also Sarah Heathcote, 'Les biens publics mondiaux et le droit international. Quelques reflexions a propos de la gestion de l'interet commun' (2002) 13 L'observateur des Nations Unies 143; Daniel Bodansky, 'What's in a Concept? Global Public Goods, International Law, and Legitimacy' (2012) 23(3) The European Journal of International Law 652, 654.

9 See Inge Kaul, Isabelle Grunberg and Marc Stern, International Cooperation in the 21st Century (Oxford University Press, 1999).

10 See, for example: Inge Kaul, Pedro Conceicao, Katell Le Goulven and Ronald U. Mendoza, Providing Global Public Goods; Managing Globalization (Oxford University Press, 2003).

11 World Bank, Effective Use of Development Finance for International Public Goods (Global Development Finance, Washington DC, 2001).

12 See, for example, Agência Francesa de Desenvolvimento, Biens publics mondiaux et développement, de nouveaux arbitrages pour l'aide? (Working paper 3 , Paris, September 2005).

13 See Bodansky, supra n 8, 668. 
regarding global public goods. These include: the centrality of consensus in negotiations on subjects of international law; ${ }^{14}$ the capacity and limitations of bilateral treaties to contribute to the management of global public goods ${ }^{15}$ and the need for substantial procedural mechanisms to implement the term's objectives: ${ }^{16}$ analysis of how international law can contribute to issues of governance and legitimacy of institutions to organize the management of these goods; ${ }^{17}$ the idea of linking global public goods to erga omnes obligations; ${ }^{18}$ and evaluation of specific issues such as energy production management. ${ }^{19}$ A perspective that deserves greater attention, and that has not yet been the focus of an in-depth study, relates to the articulation of precise obligations specific to the content of global public goods. ${ }^{20}$ More precisely: does a state have any particular obligations in international law concerning the utilization and conservation of a resource because the relevant object is considered a global public good? This chapter aims to deepen this discussion, specifically as regards marine resource management.

The main characteristics of public goods are that they are non-rival and non-excludable. ${ }^{21}$ That means that there is no rivalry between potential users of the good - everyone may use it without reducing its availability to others. The air that we breathe is commonly used as an example of a public good. Yet in this light, the term 'global public good' does not seem altogether adequate, because, as Salmon's Dictionnaire de Droit International Public explains, ${ }^{22}$ a good is a movable or immovable asset susceptible

14 Krisch, supra n 5, 40.

15 Morgera, supra n 5, 767.

16 André Nollkaemper, 'International Adjudication of Global Public Goods: The Intersection of Substance and Procedure' (2012) 23(3) The European Journal of International Law 769, 791.

17 Gregory Shaffer, 'International Law and Global Public Goods in a Legal Pluralist World' (2012) 23(3) The European Journal of International Law 669, 693; Bodansky, supra $\mathrm{n} 8,653$. In the same sense: Fabrizio Cafaggi and David D Caron, 'Global Public Goods Amidst a Plurality of Legal Orders, a Symposium' (2012) 23(3) The European Journal of International Law 645.

18 Bodansky, supra n 8, 653. See also Markus Benzing, 'Community Interests in the Procedure of International Courts and Tribunals' (2006) 5 The Law and Practice of International Courts and Tribunals 374.

19 Timothy Meyer, 'Global Public Goods, Governance Risk and International Energy' (2012) 22 Duke Journal of Comparative and International Law 319.

20 For an articulation of commons with the obligation of participation see Queffelec, supra n 5.

21 Bodansky, supra n 8, 652.

22 Jean Salmon (ed.), Dictionnaire de Droit International Public (Bruylant, 2001) 126 (author's translation). 
to appropriation, ${ }^{23}$ which may seem to contradict the notion of global public good; public generally is understood as opposed to private. For a legal scholar, the adjective evokes the public domain, which is characterized by its inalienability.

With its origins in domestic law, the distinction between public and private therefore cannot be well transposed to the international arena without significant modifications. The characterization as 'global' is, without a doubt, the element of the three-part term that is the least questionable: it denotes the global sphere. Still, a global approach is often just one of several prospective spheres of action for solving different problems. Management of the oceans is multi-scale - it can be both local and global, simultaneously. A global public good therefore can still require action at the local, national and international levels.

The divergences between the terms 'public' and 'common' may also be questioned. Why do we speak of public goods, rather than common goods, considering that the term 'public' has no meaning in international law, while the term 'common' is already legally enshrined (common interest of humanity, common heritage of mankind, common concern of humankind, etc.)? Even if 'common' is already legally enshrined, to which community does it refer? There is no international legal community representing a sociological community, more or less existent. ${ }^{24}$

Regarding marine resources more specifically, one significant outcome of the global public good for the conservation of marine resources is the relation with the marine biodiversity and the ecosystem approach. The Convention on Biological Diversity 1992 (CBD) affirms in its preamble that 'the conservation of biological diversity ${ }^{25}$ is a common concern of humankind'. Indeed, it states in Article 5 that '[e]ach Contracting Party shall, as far as possible and as appropriate, cooperate with other Contracting Parties, directly or, where appropriate, through competent international organizations, in respect of areas beyond national jurisdiction and on other matters of mutual interest, for the conservation and sustainable use of biological diversity'. ${ }^{26}$

23 The original text is as follows: 'Élément mobilier ou immobilier susceptible d'appropriation'.

${ }_{24}$ Emanuelle Jouannet, 'L'idee de Communaute Humaine' in Archives De Philosophie Du Droit, La mondialisation entre illusion et utopia (t. 47) 191.

25 'Biological diversity' is defined in Article 2 of the CBD as 'the variability among living organisms from all sources including, inter alia, terrestrial, marine and other aquatic ecosystems and the ecological complexes of which they are part: this includes diversity within species, between species and of ecosystems'.

26 See: https://www.cbd.int/doc/legal/cbd-en.pdf (accessed 20 August 2016). 
Moreover, marine biodiversity governance has lately been based on an ecosystem approach. The global public good can enforce and emphasize this perspective. Politically speaking, the ecosystem approach has been included as a perspective that should be integrated for the sustainable development of the oceans in the Plan of Implementation of the World Summit on Sustainable Development. ${ }^{27}$ The commitment made was to implement the ecosystem approach by $2010 .{ }^{28}$ In the context of the six Aichi Biodiversity Targets, adopted in 2010, the objective is to achieve the ecosystem approach in $2020 .{ }^{29}$ In the same way, the Outcomes Document 'The Future We Want', adopted at the United Nations Conference on Sustainable Development (UNCSD, or 'Rio $+20^{\prime}$ '), in its clause 158 , provided a commitment to implement the ecosystem approach in the marine environment. ${ }^{30}$ Consequently, the effect of the approach is still more political than legal. For the purpose of the CBD, 'ecosystem' means a 'dynamic complex of plant, animal and micro-organism communities and their non-living environment interacting as a functional unit'. ${ }^{31}$ The CBD does not create an obligation for states to cooperate by adopting an ecosystem approach. This said, the Conference of the Parties has brought this perspective to the governance of marine and coastal zone biodiversity. ${ }^{32}$ Considering that marine biodiversity is not yet managed with the most appropriate instruments, the global public good concept can contribute to extending the interpretation of the conservation of marine biodiversity.

According to the UNDP, the term 'public' is justified by the 'triangle of publicness' that characterizes these goods. The global public good is 'public three times over': it is public in its consumption, with free and non-excludable access to the good; public in the participatory process, with an open and inclusive political process; and public in the distribution

\footnotetext{
2730 (d); 31 (c); 44 (e); 70 (b) http://www.un.org/esa/sustdev/documents/WSSD_ POI_PD/English/WSSD_PlanImpl.pdf (accessed 3 August 2010).

28 Plan of Implementation of the World Summit on Sustainable Development, 16.

29 https://www.cbd.int/sp/targets/ (accessed 5 September 2016).

$30 \mathrm{http}: / / \mathrm{www} . u n . o r g / d i s a b i l i t i e s / d o c u m e n t s /$ rio20_outcome_document_com plete.pdf (accessed 5 September 2016).

31 Article 2.

32 COP 2 has mentioned the ecosystem approach as a base of action, but did not provide for criteria to implement it. Decision II/10 (1995). https://www.cbd.int/ marine/imcam.shtml (accessed 3 September 2016). The COP 7 adopted 12 principles and five orientations in its Decision VII/11 in order to connect the ecosystem approach to the marine conservation of resources.
} 
of privileges, from which everyone may benefit. ${ }^{33}$ It appears there are currently very few global public goods that reflect these three characteristics simultaneously. These objectives can only come to pass in the context of an existing international society - still just a project, not a reality. In short, the global public good still lacks its own specific legal regime. It is not legal, despite many references to it in different areas of international law. This finding does not mean that commitments and specific obligations cannot be attributed to the management of so-called global public goods. It is possible, for example, to link them to terminology that is already consolidated in international law, which has some of the characteristics of global public goods.

\subsection{From Global Public Goods to Common Heritage of Humankind and to Global Commons}

With respect to both living and non-living marine resources, the terminology for global public good is akin to the terminology related to marine resources as common heritage of mankind, ${ }^{34}$ concerning mineral seabed resources; and in global commons ${ }^{35}$ related to resources of overlying water.

33 UNDP, Providing Global Public Goods, Managing Globalization. 25 Questions \& Answers (UNDP/ODS, 2002) 3, 5, http://web.undp.org/globalpublicgoods/globa lization/pdfs/ques-ans.pdf (accessed 10 May 2015).

34 On this subject, see Pierre-François Mercure, 'L'échec des modeles de gestion des ressources naturelles selon les caracteristiques du concept de patrimoine commun de l'humanité' (1997) 28 Revue De Droit D'ottawal Ottawa Law Review 45; François-Guy Trébulle, 'La propriété à l'épreuve du patrimoine commun, le renouveau du domaine universel' in Etudes offertes au Professeur Malinvaud (LexisNexis, 2007); Erik Franckx, 'The International Seabed Authority and the Common Heritage of Mankind: The Need for States to Establish the Outer Limits of their Continental Shelf' (2010) 25 The International Journal of Marine and Coastal Law 543, 567; Michael W Lodge, 'The Common Heritage of Mankind' (2012) 27 The International Journal of Marine and Coastal Law 733, 742; John E Noyes, 'The Common Heritage of Mankind, Past, Present, and Future' (2012) 20 Denver Journal of International Law and Policy 447; Kemal Baslar, The Concept of the Common Heritage of Mankind in International Law (Nijhoff Publishers, 1998); Scott J Shackelford, 'The Tragedy of the Common Heritage of Mankind' (2009) 28 Stanford Environmental Law Journal 109; C Joyner, 'Legal Implications of the Concept of the Common Heritage of Mankind' (1986) 35 International and Comparative Law Quarterly 1986.

35 Parance and de Saint Victor, supra n 1; Christian Deblock and Olivier Delas, Le bien commun comme reponse politique a la mondialisation (Bruylant, 2003); José Luis Gordillo, La protección de los bienes comunes de la humanidad, un desafío para la política y el derecho del siglo XXI (Editorial Trotta, 2006); Charlotte Ku, 'The 
While the concept of common heritage of humankind is meant to be applied to spaces or resources, that is not necessarily the case with global public goods. The use of global public goods is not connected to the internationalization or exclusive use of a good, but rather to effective cooperation for effective and concrete management of the good. From that perspective, the term can complement and broaden the meaning of the concepts common heritage of humankind and global commons, to correspond more precisely to the idea of cooperation for the conservation of the resource. ${ }^{36}$ It is possible to identify this result of cooperation in a global commons regime where there is no control of a particular state or organization, such as the sea, the air, the cyberspace, but there is an open use for all the states, organizations and individuals. ${ }^{37}$

On the other hand, the legal regime for the common heritage of humankind differs from the concept of global public good by virtue of the possibility for exclusive use of the seabed in certain circumstances. Still, this possibility for exclusive use - through contracts for seabed exploration, for example - does not preclude the use of analytical tools that could enforce the obligation of cooperation in the management of marine resources under private or collective ownership. ${ }^{38}$

In short, the practical effect of the term global public good, in the area of marine resources, consists in articulating those terms already

Concept of Res Communis in International Law' (1990) 12 History of European Ideas 4.

36 The relevance of the concept of global public good for cooperation has been highlighted by several authors, including Scott Barrett, Why Cooperate? The Incentive to Supply Global Public Goods (Oxford University Press, 2007); Cafaggi and Caron, supra $\mathrm{n} \mathrm{17,645.} \mathrm{On} \mathrm{the} \mathrm{connection} \mathrm{between} \mathrm{environmental} \mathrm{preserva-}$ tion and cooperation see Morgera, supra n 5, 753.

37 Grotius, in his pamphlet De Mare Liberum, 1609, highlighted this idea, saying that from the point of view of navigation or of fisheries, the sea is common to all and is not susceptible of occupation. In this sense: 'Tel est, par une double raison, l'air qui nous environne; et parce qu'il ne peut être occupé, et parce qu'il se prête en commun à l'usage de tous. Pour les mêmes raisons, l'élément des mers est commun à tous, trop immense pour être possédé par personne, et dispose d'ailleurs merveilleusement pour l'usage de tous, qu'on le considère soit au point de vue de la navitation, soit même à celui de la pêche'. See de Grooit, Huig ('Grotius'), $L a$ liberté des mers (Mare Liberum) (Éditions Panthéon0-Assas, 2013) 75. See also Alfred Thayer Mahan, The Influence of Sea Power upon History 1660-1783 (Dover Publications, 1987); Tara Murphy, 'Security Challenges in the 21st Century Global Commons' (2010) 28 Yale Journal of International Affairs 30; Jared R Wigginton, 'Governing a Global Commons, Sharks in the High Seas' (2014) 25 Villanova Environmental Law Journal 431; Rossi, supra $n 3$.

38 On the subject of the theme of individual and collective property in the context of global public goods see Cafaggi and Caron, supra n 17, 796. 
enshrined in public international law, broadening their scope by linking them with obligations related to the conservation of marine resources. Two of the most salient specific obligations consolidated in international law are the obligation to cooperate and the obligation of due diligence. Other obligations might include the obligation to act according to the precautionary principle; ${ }^{39}$ however, unless it could be considered as part of the due diligence obligation, ${ }^{40}$ we cannot yet affirm that this obligation is enshrined in international law. Obligations should also have national and international impacts, which is the case for the two obligations cited above. Thus, the obligation to cooperate and the obligation of due diligence will be analysed in the context of conservation of marine resources, considering there are significant limitations to their implementation.

\section{THE OBLIGATION TO COOPERATE FOR THE CONSERVATION OF THE MARINE ENVIRONMENT}

Content related to management of global public goods still does not contribute to the implementation of the obligation to cooperate for the conservation of the marine environment. Considering that the concept of global public good still is not legally operational, other concepts which have already been consolidated in legal terms can be considered in the alternative. Global commons, for example, possesses a clearer legal scope when it comes to the regime applied to marine living resources in the high seas ${ }^{41}$ In turn, common heritage of mankind has a more limited scope with regard to management of marine resources. Before

39 On this subject see Bénédicte Sage-Fuller, The Precautionary Principle in Marine Environmental Law (Routledge, 2013); Simon Marr, 'The Southern Bluefin Tuna Cases, The Precautionary Approach and Conservation and Management of Fish Resources' (2000) 11(4) European Journal of International Law 815, 831.

40 See Responsibility and obligations of States sponsoring persons and entities in the context of activities in the Area [2011] ITLOS Advisory Opinion no. 17 [125]-[135].

${ }_{41}$ On this subject see Stuart Kaye, 'Enforcement Cooperation in Combating Illegal and Unauthorized Fishing: An Assessment of Contemporary Practice' (2014) 32 Berkeley Journal of International Law 316, 329; Anastasia Telesetsky, Laundering Fish in the Global Undercurrents, Illegal, Unreported, and Unregulated Fishing and Transnational Organized Crime' (2014) 41 Ecology Law Quarterly 939, 998; Celso de Albuquerque Mello, Alto-mar (Renovar, 2001). The term 'commons' will be used in the context of the res communis regime. 
analysing the existing obligation of cooperation for these two terms already consolidated in international law, it will be demonstrated that the obligation to cooperate for the conservation of marine resources and for the implementation of the ecosystem perspective in the management of the marine biodiversity exists in international law, but there are still gaps.

The principle of cooperation is a general principle of public international $\mathrm{law}^{42}$ and more specifically of international environmental law. States' collective action in the name of the common interest can be observed in several environmental treaties or other instruments, particularly in the preambles that call for cooperation among subjects of international law. ${ }^{43}$ Regarding the International Court of Justice (ICJ), we may cite the 2010 decision in Pulp Mills on the River Uruguay (Argentina v Uruguay), which affirmed the existence of a general obligation to cooperate regarding the environment, in the following terms: 'That applies to all obligations established by a treaty, including procedural obligations which are essential to co-operation between States. ${ }^{44}$ In the field of biodiversity, the CBD states that

[e]ach Contracting Party shall, as far as possible and as appropriate, cooperate with other Contracting Parties, directly or, where appropriate, through competent international organizations, in respect of areas beyond national

42 See: UN Charter, Art. 1, item 3; Art. 11, item 1; Art. 13, item 1(a), (b); Declaration 2625 (XXV) on the principles of international law relating to friendly relations and cooperation among States.

43 United Nations Convention to Combat Desertification in Those Countries Experiencing Serious Drought and/or Desertification, Particularly in Africa 1992; African Convention on the Conservation of Nature and Natural Resources 2003; Convention on International Trade in Endangered Species of Wild Fauna and Flora 1973; the preamble to the Convention on the Conservation of Migratory Species of Wild Animals (CMS 1979; UN Framework Convention on Climate Change (1992); Rio Declaration on Environment and Development 1992: 'States shall cooperate in a spirit of global partnership in the process of conserving, protecting and restoring the health and integrity of the terrestrial ecosystem' (Principle 7). The Declaration highlights the application of the principle in science and technology (Principle 9), in trade (Principle 12), or with regard to notifying the states of natural disasters and other emergency situations of the same order likely to have transboundary effects (Principle 18), or information and consultation with the states likely to be affected by the activities that may have transboundary effects on the environment (Principle 19). The Declaration ends with Principle 27: 'States and people shall cooperate in good faith and in a spirit of partnership in the fulfilment of the principles embodied in this Declaration and to the progressive development of international law in the field of sustainable development'.

44 Pulp Mills on the Uruguay River Case (Argentina v Uruguay) [2010] ICJ [146]. 
jurisdiction and on other matters of mutual interest, for 'the conservation and sustainable use of biological diversity'. ${ }^{45}$

The obligation of cooperation on environmental issues is also present in the law of the sea. ${ }^{46}$ For example, Article 192 of the UN Convention on the Law of the Sea 1982 (UNCLOS) lays out a general obligation, affirming that 'states have the obligation to protect and conserve the marine environment'. Customary law also serves as a source of recognition of this obligation, which can be observed in several rulings related to the sea: '.. the obligation to cooperate is, by virtue of Part XII of the UNCLOS, and international law overall, a fundamental principle in the prevention of pollution of the marine environment from which laws originate that can be enforced by the Court ....47

One of the instruments of cooperation related to environmental protection highlighted by the Court in the aforementioned case is environmental impact assessment. On the impact assessment, the Court stated that the practice

in recent years has gained so much acceptance among States that it may now be considered a requirement under general international law to undertake an environmental impact assessment where there is a risk that the proposed industrial activity may have a significant adverse impact in a transboundary context, in particular, on a shared resource. ${ }^{48}$

Based on this decision, it can be argued strongly that the environmental impact assessment has a purpose that goes beyond receiving authorization for a project.

Another possible outcome of the cooperation is the implementation of the ecosystem approach in the management of marine biodiversity. The CBD's preamble states that 'the conservation of biological diversity is a common concern of humankind'. In addition to this, as was previously stated, Article 5 states that Contracting Parties shall cooperate in order to achieve the conservation and the sustainable use of biological diversity'. ${ }^{49}$ The preamble does not provide a binding obligation, which reduces

45 See: https://www.cbd.int/doc/legal/cbd-en.pdf (accessed 20 August 2016).

46 See Nilufer Oral, Regional Co-Operation and Protection of the Marine Environment under International Law, The Black Sea (Martinus Nijhoff Publishers, 2013).

47 The Mox Plant Case (Ireland v United Kingdom) [2001] ITLOS provisional measures [82].

48 Pulp Mills on the Uruguay River Case (Argentina v Uruguay) [2010] ICJ [204].

49 See: https://www.cbd.int/doc/legal/cbd-en.pdf (accessed 20 August 2016). 
the legal impact of the 'common concern of humankind' provision. Nonetheless, Article 5 provides an obligation of cooperation regarding areas beyond national jurisdiction, which must be seen as directly connected to marine biodiversity. ${ }^{50}$

The basing of marine governance on an ecosystem approach changes the pattern in marine resources management considering not only nature as a set of economic resources and services, ${ }^{51}$ but as a complex functional unit. This approach leads to the identification of different kind of instruments in order to enable cooperation by an integrated management based on, for instance, the best technology available, ${ }^{52}$ proper compensation ${ }^{53}$ and an appropriate interpretation of the precautionary approach. ${ }^{54}$

Given this scenario, this chapter will proceed to analyse the limitations of conservation of the marine environment through, first, the global commons regime, and, second, the common heritage of humankind, for the implementation of the obligation of cooperation in order to conserve marine resources.

\subsection{Limitations of the Global Commons Concept}

The global commons legal regime, established on the principle of open access, may not contribute to the implementation of cooperation among subjects of international law for the conservation of marine resources. The over-exploitation of these resources, evaluated through reports and

50 See the works of the Preparatory Committee on the elements of a draft text of an international legally binding instrument under the UN Convention on the Law of the Sea on the conservation and sustainable use of marine biodiversity of areas beyond national jurisdiction (BBNJ), Earth Negotiations Bulletin, 25 (114) (6 September 2016).

51 Volkmar Hartje, Axel Klaphake and Rainer Schliep, The International Debate on the Ecosystem Approach: Critical Review, International Actors, Obstacles and Challenges (Federal Agency for Nature Conservation, 2003) 12.

52 Secretariat of the Convention on Biological Diversity, 'The Ecosystem Approach: CBD guidelines' (2004) 6.

53 Gabriela Garcia B. Lima, La compensation en droit de l'environnement: un essai de typologie (PHD thesis, Aix Marseille Université/Centre Universitaire de Brasília, 2014) 54.

54 Aline Jaeckel, The International Seabed Authority and Marine Environmental Protection: A Case Study in Implementing the Precautionary Principle (PhD thesis, University of New South Wales, Australia, 2015); Marr, supra n 39; Annie Cudennec, 'La politique européenne de gestion et d'exploitation durable des ressources marines vivantes' in A Monaco and P. Prouzet (eds), Gouvernance des mers et des oceans. Collection 'mer et ocean' (ISTE éditions, May 2015), vol. 7, 115-140. 
rulings, in the scope of the Food and Agriculture Organization (FAO), ${ }^{55}$ the ICJ ${ }^{56}$ and other organizations, reveals a lack of substantial and procedural instruments to enforce cooperation.

The main marine resource that can be analysed through the lens of this regime is the fisheries resource. Therefore, fishing will be central to the analysis of the implementation of the global commons regime for conservation of the marine environment. Considering that the content of the global public good is cooperation, it is pertinent to connect it to the global commons regime and to demonstrate the limits for the implementation of states' obligation to cooperate in managing marine resources that lie within or outside their respective national jurisdictions.

Characterized by free access and non-excludability, the traditional global commons regime is incapable of limiting, on its own, the risk of degradation and depletion of the resources. ${ }^{57}$ In this sense, Hardin's 'Tragedy of the Commons' idea ${ }^{58}$ has described the abuse that arises in cases of common goods: as the good is common, and access to the good is free and unregulated, there is a high risk for over-exploitation.

Global commons, or traditionally the res communis regime, extended from Roman law and was soon after cultivated by sixteenth-century theological jurists (Vitoria, Suarez), and later systematized by Grotius' school of natural law. ${ }^{59}$ It consists in making an effort to triumph over all through self-centred behaviour in competing territorial activities. ${ }^{60}$ The high seas provide the best illustration: free use for all, with freedom of navigation for all flags. Article 87 of UNCLOS provides that 'the high seas are open to all States, be they coastal or landlocked'; and Article 89 states

55 FAO, Yearbook of Fishery and Aquaculture Statistics (2014) http://www.fao. org/fishery/statistics/yearbook/en (accessed 5 May 2016).

56 See Sandrine Maljean-Dubois and Yann Kerbrat, 'La Cour Internationale de Justice face aux enjeux de protection de l'environnement, réflexions critiques sur l'arrêt du 20 avril 2010, Usines de pâte à papier sur le fleuve Uruguay (Argentine c. Uruguay)' (2011) 1 RGDIP t. CXV 39, 75; Southern Bluefin Tuna (New Zealand - Japan, Australia - Japan) [1999] ITLOS Provisional Measure.

57 Alexandre-Charles Kiss, 'La notion de patrimoine commun de l'humanité' (1982) RCADI t. 175, 243.

58 According to Hardin: 'The tragedy of the commons as a food basket is averted by private property, or something formally like it. But the air and waters surrounding us cannot readily be fenced, and so the tragedy of the commons as a cesspool must be prevented by different means, by coercive laws or taxing devices that make it cheaper for the polluter to treat his pollutants than to discharge them untreated.' Garrett Hardin, 'The Tragedy of the Commons' (1968) 13(162) Science 1246.

59 de Grooit, Huig ('Grotius'), supra n 37, 75.

60 Pierre-Marie Dupuy, Droit International Public (11th edn, Dalloz, 2012) 819. 
that 'no state may legitimately purport to subject any part of the high seas to its sovereignty'.

The reality is well substantiated, but to what extent can the notion of a global public good avoid this tragedy? It may aid in the interpretation of the term to call for cooperation among subjects of international law in the management of marine resources. Cooperation may be implemented both in the Area, the seabed beyond national jurisdiction, or in areas under states' jurisdiction - more precisely, their (200 nautical mile) Exclusive Economic Zones (EEZs) if these have been claimed. The vagueness of obligations in this area, particularly with regard to fishing activity, is clear both as regards the ship's flag state and the coastal state. ${ }^{61}$ Advisory Opinion 21 of the International Tribunal for the Law of the Sea (ITLOS) highlighted some of these obligations for seven African states. ${ }^{62}$

In the context of the Convention related to determining minimum access and exploration of fishery resources in the interior of maritime zones under the jurisdiction of member states of the Sub-Regional Fisheries Commission (CSRP), which was examined by the ITLOS in Advisory Opinion 21, we find gaps related to states' cooperation in addressing illegal fishing. There are more substantial instruments outlining the obligations of coastal states regarding the sustainable management of shared stocks and stocks of common interest - especially regarding tuna and small deep sea creatures - than we find for obligations for the ship's state. The coastal state's obligations include: (a) to cooperate on any measures necessary to assure the conservation and development of stocks; ${ }^{63}$ (b) to ensure there will not be over-exploitation of these resources; and (c) to take measures in line with those of other organizations that address the issue, such as the International Commission for the Conservation of Atlantic Tuna (ICCAT), both in the EEZs of CSRP member states and in states that are members of other organizations with similar missions. Moreover, the state is called upon to verify whether the conservation and management of these resources are being carried out in accordance with the most reliable scientific findings, which are available to all CSRP member states in the terms of Article 2(2) of UNCLOS. ${ }^{64}$

The Virginia $G$ case had already provided greater clarity regarding coastal states' obligations vis-à-vis conservation and management of

\footnotetext{
61 See Kaye, supra n 41, 329; Telesetsky, supra n 41, 998.

62 Cape Verde, Islamic Republic of Mauritania, Senegal, Gambia, Guinea Republic, Guinea-Bissau and the Republic of Sierra Leone.

63 Request for an advisory opinion by the Sub-Regional Fisheries Commission (SRFC) [2015] ITLOS [189]. Art. 61(2) of UNCLOS.

64 Art. 61(2) of UNCLOS.
} 
biological resources in EEZs, listing the following activities: ${ }^{65}$ ' $\ldots$ adopt laws and regulations that determine the conditions of access for foreign fishing ships in the EEZ (art. 56(1) and art. 62(4) of the Convention)'. In terms of Article 62(4), these laws and regulations must be compatible with the Convention. The ITLOS notes that the measures in question are management related and that there is no exhaustive list of what may or may not be done by the coastal state. ${ }^{66}$ Similarly, Advisory Opinion 21 indicates that the coastal state may adopt 'all measures, including boarding, inspection and seizure, and the necessary legal measures to ensure that the laws and regulations adopted in accordance with the Convention are respected'. ${ }^{67}$

A significant limitation to cooperation in fisheries management stems from the fact that there are no general obligations for all states, but rather only for member states of specific fisheries commissions. ${ }^{68}$ Overarching, broad-based obligations would reduce potential damage to the marine environment, considering that the sea has no borders. To be effective, such measures for the management and conservation of fisheries must address species stocks in the full zone of distribution and along every migratory path. ${ }^{69}$ States that fish in adjacent sectors must implement the necessary measures to conserve these stocks. ${ }^{70}$ In this sense, the notion of global public good highlights the need for better management of these resources locally, nationally and internationally.

Limitations on the obligation to cooperate are likewise reflected in Judge Paik's Statement that Advisory Opinion 21 should have evaluated the boundaries between, first, the obligation to cooperate of a member state of the fisheries commission involved in the opinion; and, secondly, the rights of the coastal state to conserve and manage the biological resources in its EEZ. ${ }^{71}$ The Opinion also failed to guarantee any greater precision with regard to the obligation to cooperate, which could have come from determining that it would be considered a breach of the obli-

65 See: Carina Costa de Oliveira and Natália da Silva Gonçalves, 'Comentários ao caso m/v 'Virginia (Panamá c. Guiné-Bissau), 14 de abril de 2014' in Nitish Monebhurrun, Decisões da corte internacional de justiça e do tribunal internacional sobre o direito do mar (2014) 2 RDI, v. 12 55, 63.

66 The $M / V$ 'Virginia G' Case (Panama v Guinée-Bissau) [2014] ITLOS [212], [213].

Request for an advisory opinion by the Sub-Regional Fisheries Commission (SRFC) [2015] ITLOS [105].

68 Ibid, [69].

69 Ibid, [196], [198].

70 Ibid, [196].

71 Ibid, Judge Paik's opinion [31]. 
gation if a state refused to negotiate or stalled in the presentation of its responses or conservation and management measures. ${ }^{72}$

It may be observed that advances in the interpretation of the obligation of cooperation are linked to greater precision regarding specific obligations to cooperate for the majority of states at the international level. There have been advances, for example, regarding coastal states' obligations vis-à-vis illegal fishing in areas under the jurisdiction of members of the Commission that solicited Advisory Opinion 21. Still, general obligations for cooperation require greater precision. Other areas, such as freedom of navigation and the flag of convenience issue, ${ }^{73}$ should also be analysed more closely from the perspective of the conservation of marine resources. Beyond the limitations of the global commons regime, it is important to understand the limitations of the regime of the common heritage of mankind when it comes to fomenting international cooperation for the conservation of marine resources.

\subsection{The Limitations of the Common Heritage of Humankind Regime}

The content of the term common heritage of humankind is still very limited when it comes to the conservation of marine resources. ${ }^{74}$ In principle, this classification deals with the theoretically sustainable common management of resources under this regime. ${ }^{75}$ To assess the limitations of this legal regime for the conservation of marine resources, with content of cooperation for management of this good, we must analyse the concept of common heritage of mankind; the limitations of its content as regards guaranteeing cooperation in management of marine resources; and the example of its limitations in the classification of Antarctica.

The concept of common heritage of humankind as applied to the seabed's mineral resources was first raised by the Ambassador of Malta

\footnotetext{
72 Ibid, [37].

73 This being the phenomenon of vessels sailing under the flags of states to which they have sometimes only a tenuous connection.

74 See Kiss, supra n 57; Lodge, supra n 34, 742; Noyes, supra n 34; Baslar, supra $\mathrm{n}$ 34; Shackelford, supra n 34; Joyner, supra n 34; Daniel Bardonnet, 'Le projet de Convention de 1912 sur le spitsberg et le concept de patrimoine commun de l'humanité' in Mélanges Rene-Jean Dupuy, Humanité et Droit International (Pedone, 1991) 13.

75 Bernard Edelman, 'Entre Personne Humaine et Materiau Humain, Le Sujet de Droit' in Marie-Angèle Hermitte and B Edelman (eds), L'homme, La Nature et Le Droit (Bourgois, 1988) 136; Kiss, supra n 57.
} 
to the UN General Assembly in $1967 .{ }^{76}$ The UNCLOS established an international system for the management of funds for the benefit of humanity managed by the International Seabed Authority, which was established by the 1994 Implementation Agreement. This instrument was necessary to overcome several developed states' concerns about ratifying the Convention, which - when the Implementation Agreement was adopted - finally came into force in 1994. In turn, through an Advisory Opinion, the Seabed Chamber of ITLOS took the position that its objective is to provide substantial content to the regime of common heritage of humankind. ${ }^{77}$ The following paragraphs serve as examples:

The role of the sponsor State, such as it was determined in the Convention, is to contribute to the defense of the common interest of all States through the correct application of the common good for mankind, which requires reliable configuration of the obligations set forth in Part XI. ${ }^{78}$

The following passage speaks also to this point:

In the sphere of the obligation to assist the Authority acting on behalf of mankind as a whole, while deciding what measures are reasonably appropriate, the sponsoring State must take into account, objectively, the relevant options in a manner that is reasonable, relevant and conducive to the benefit of mankind as a whole. It must act in good faith, especially when its action is likely to affect prejudicially the interests of mankind as a whole. ${ }^{79}$

The introduction of the common heritage of humankind was also invoked for Antarctic regulation. ${ }^{80}$ While the signatory states of the Antarctic Treaty ${ }^{81}$ agreed to refer to the interest of mankind they did not, however, agree on a reference to the common heritage of mankind. The preambles of the Convention on the Conservation of Antarctic Marine Living Resources

76 Kiss, supra n 57; Lodge, supra n 34, 742; Noyes, supra n 34; Kemal Baslar, supra $\mathrm{n}$ 34; Shackelford, supra $\mathrm{n}$ 34; Joyner, supra n 34; Bardonnet, supra $\mathrm{n} 74$.

77 Responsibility and obligations of States sponsoring persons and entities in the context of activities in the Area [2011] ITLOS Advisory Opinion no. 17.

78 Ibid, [76].

79 Ibid, [230].

80 See Reid, supra n 3, 139.

81 The preamble to the Antarctic Treaty states that: 'Recognizing that it is in the interest of all mankind that Antarctica shall continue forever to be used exclusively for peaceful purposes and shall not become the scene or object of international discord'. The Antarctic Treaty, Washington, 1959, http://www.ats.aq/e/ats_keydocs. htm (accessed 4 August 2016). 
1980 (CCAMLR) $^{82}$ and the Protocol on Environmental Protection to the Antarctic Treaty 1991 (the Madrid Protocol) ${ }^{83}$ reaffirmed the 'interest of mankind' as a motivation of the parties, but did not make reference to the notion of common heritage. It seems to be difficult to agree upon this notion in a context where there are different signatory states claiming sovereignty over the region. ${ }^{84}$ In the same way, the CBD affirms that 'the conservation of biological diversity is a common concern of humankind' but does not refer to common heritage. In practice, however, this does not impede states from adopting stricter rules for protection, which resemble those that qualify as common heritage of mankind. ${ }^{85}$

The common heritage of humankind regime is indeed quite limited when it comes to implementing the obligation of cooperation for management of marine resources. Even though this regime was developed before the emergence of the concept of global public goods, it is important to seek to operationalize the term by establishing specific legal obligations linked to the cooperation of subjects of international law.

Beyond the obligation to cooperate, the obligation of due diligence requires specific analysis of its potential contribution as regards the conservation of marine resources.

\subsection{The Potential Contribution of the Obligation of Due Diligence for the Conservation of the Marine Environment}

The obligation of due diligence ${ }^{86}$ suggests a greater coordination by subjects of international law for the management of marine resources, but still with several limitations. Due diligence obligations are states'

82 Preamble: 'Believing that it is in the interest of all mankind to preserve the waters surrounding the Antarctic continent for peaceful purposes only and to prevent their becoming the scene or object of international discord'. Convention on the Conservation of Antarctic Marine Living Resources, Canberra, 1980 https:// www.ccamlr.org/en/organisation/camlr-convention (accessed 4 August 2016).

83 'Convinced that the development of a comprehensive regime for the protection of the Antarctic environment and dependent and associated ecosystems is in the interest of mankind as a whole'. Protocol on Environmental Protection to the Antarctic Treaty, http://www.ats.aq/e/ats_keydocs.htm (accessed 4 August 2016).

${ }^{84}$ Gilbert Guillaume, 'Le statut de l'antarctique, Réflexions sur quelques problèmes récents' in Mélanges offerts à René-Jean Dupuy (Pédone, 1991) 174.

85 This aspect is reflected in the Madrid Protocol.

86 For an interesting description of the content of the 'due diligence' obligation, see: Responsibility and obligations of States sponsoring persons and entities in the context of activities in the Area [2011] ITLOS Advisory Opinion no. 17 [117]-[120]. 
obligations to adopt substantive and procedural instruments related to monitoring activities that are under their management. It is important to examine this concept, its variability and criticisms regarding the difficulty of implementing and enforcing these obligations when it comes to protecting marine resources.

States are obligated to carry out due diligence over several maritime activities, in areas both within and outside their jurisdiction. States and international organizations are expected to act to avoid any possible harm. This represents a conduct-specific obligation, which has been referred to in decisions and Advisory Opinions in the ICJ and the ITLOS. In the 20 April 2010 decision in the Pulp Mills on the River Uruguay case, for example, the ICJ held that

[t]he principle of prevention, as a customary rule, has its origin in the due diligence of the state over its territory. It is an obligation of every state not to use its territory for purposes contrary to the rights of other States (Corfu Channel, United Kingdom of Great Britain and Northern Ireland v Albania, Decision 1949, p.22)... A state is thus obliged to use all the means at its disposal in order to avoid activities which take place in its territory, or in any area under its jurisdiction, causing significant damage to the environment of another state. This Court has established that this obligation 'is now part of the corpus of international law relating to the environment' (Legality of the Threat or Use of Nuclear Weapons, Advisory Opinion, I.C.J. Reports 1996 (I), 242, para. 29). ${ }^{87}$

Due diligence obligations were similarly mentioned in Advisory Opinions $17^{88}$ and $21^{89}$ of the ITLOS, with the same interpretation as that of the ICJ.

Application of the concept of due diligence has, however, been inconsistent. ${ }^{90}$ In the assessment of whether a state has been diligent or not, that state's conditions for carrying out its diligence obligations are taken into account. ${ }^{11}$ The problem with this inconsistency lies in identifying a minimum amount of due diligence that could be required of all states

87 Pulp Mills on the Uruguay River Case (Argentina v Uruguay) [2010] ICJ [101].

88 In the Advisory Opinion of the ITLOS on the responsibility and obligations of States in the context of activities undertaken in the Area, the obligation of due diligence has been identified as having a variable content. See Responsibility and obligations of States sponsoring persons and entities in the context of activities in the Area [2011] ITLOS Advisory Opinion no. 17 [117].

${ }_{89}$ Request for an advisory opinion by the Sub-Regional Fisheries Commission (SRFC) [2015] ITLOS Advisory Opinion no. 21 [131]-[139].

90 Responsibility and obligations of States sponsoring persons and entities in the context of activities in the Area [2011] ITLOS Advisory Opinion no. 17 [117].

91 Ibid. 
as regards protection of marine resources. Faced with these interpretive limitations, it is worth analysing the limitations on conservation of these resources in areas under the jurisdiction of states, and the limitations of the regime of common heritage of humankind for their conservation.

\subsection{Limitations of Conservation of Marine Resources in Areas under State Jurisdiction}

Due diligence obligations are insufficient to guarantee the necessary conservation of marine resources, and in particular of fishery resources, in areas under states' jurisdiction. Advisory Opinion 21 of the ITLOS, which addressed the responsibility of the ship's flag state over illegal fishing, provides an interesting example as it is in accordance with applicable treaties and precedents related to the interpretation of states' due diligence obligations. What is more, the decision reveals the limitations of these obligations as regards the conservation of marine resources.

Advisory Opinion 21 interpreted the obligations of due diligence related to fishing in areas under states' jurisdiction. The ITLOS, before analysing the substantive questions, defined what is considered to be 'illegal, undeclared and unregulated fishing',92 and the meaning of 'conservation of biological resources' in the EEZ of member states of the Sub-Regional Fisheries Commission. ${ }^{93}$ Other important definitions were of 'fishing ship', 94 'shared stocks', ${ }^{95}$ and 'common interest stocks' ${ }^{96}$

Fishing ships must obtain authorization from a Commission member state to establish their quota for fishing. To do this, the ship must present

92 The definitions of illegal fishing, undeclared fishing and unregulated fishing are laid out in Art. 2(4) of the CMA. The Advisory Opinion reiterated that these definitions were inspired in the International plan of action designed to prevent and eliminate this type of fishing, drafted and adopted in 2001 by the FAO (available at: http://www.fao.org/docrep/003/y1224e/y1224e00.htm (accessed 15 May 2016)); and in the Accord related to measures taken by the port State aiming to prevent and eliminate illegal fishing, adopted in 2009 (available at: http://www.fao. org/fishery/topic/166283/en paragraph 91 (accessed 15 May 2016)).

93 Cape Verde, Islamic Republic of Mauritania, Senegal, Gambia, Guinea Republic, Guinea-Bissau and the Republic of Sierra Leone. Request for an advisory opinion by the Sub-Regional Fisheries Commission (SRFC) [2015] ITLOS Advisory Opinion no. 21 [189], [191]. The term is used to mean conservation, development. The court says Art. 61 of the Convention gives some indication of what would be sustainable management.

94 Request for an advisory opinion by the Sub-Regional Fisheries Commission (SRFC) [2015] ITLOS Advisory Opinion no. 21 [99].

95 Ibid, [184].

96 Ibid, [185]. 
declarations of capture, as noted in its fishing log, at the state's port and must not use illegal materials for its fishing. The ship must notify the coastal state of its entrance and exit from maritime space under the jurisdiction of Commission member states. ${ }^{97}$

According to the ITLOS, the ship's flag state has specific due diligence obligations related to illegal fishing. ${ }^{98}$ They include: (a) to take all necessary measures to verify that ships are complying with laws and regulations adopted by the CSRP member states related to biological resources in their EEZs; ${ }^{99}$ (b) to verify that ships do not take part in any activities related to unregulated fishing in CSRP member states' EEZs; ${ }^{100}$ (c) to take all necessary measures to ensure that fishing ships do not take part in activities that are unfavourable to the conservation of the marine environment and conservation of marine biological resources; ${ }^{101}$ and (d) to allow authorities from the coastal state to board the ship to investigate and monitor fishing activities.

As the Advisory Opinion pointed out, illegal fishing can only be considered the responsibility of the ship's flag state in the case of breaches of the due diligence obligations cited above. The result-based obligation cannot be determined without a previous assessment of the obligation regarding conduct. ${ }^{102}$ If the flag state has taken all the necessary and appropriate measures to comply with obligations for certain conduct, it shall not be liable for any damage caused to the marine environment. This is one of the principal limitations of states' due diligence obligations. In spite of the existence of more precise regulations regarding illegal fishing, we still find limitations when it comes to ensuring that regulations guarantee appropriate management of marine resources, in accordance with conduct- and results-based obligations. Beyond this particular issue, it is necessary to analyse the limitations of the regime of common heritage of humankind for conservation of marine resources.

\subsection{Limitations of the Regime of 'Common Heritage of Humankind' for Conservation of Marine Resources}

States' and international organizations' due diligence obligations are not well defined with regard to the management of marine resources. Using

\footnotetext{
97 Ibid, [113].

98 Ibid, [125]-[132].

99 Ibid, [114].

100 Ibid, [114].

101 Ibid, [116], [138].

102 Ibid, [129].
} 
the idea of the global public good as a basis, broadening the content of exclusivity of use to include content for management, greater implementation of obligations connected to marine resource conservation would be possible. This chapter next therefore provides an overview of the current context of exploration and investigation of the seabed, the articulation of obligations of due diligence and conservation of the seabed, and the limitations of these obligations with respect to achieving the desired results.

The current context of seabed activities is that while there are still no exploitation contracts, there are several exploration contracts ${ }^{103}$ for polymetallic sulfides. ${ }^{104}$ Despite the fact that it has not yet been determined what damage might be caused in this area and the lack of concrete cases ruling on these activities, there are already signs of direct obligations of states under the Seabed Authority ${ }^{105}$ and of the criteria for the obligation of due diligence that states must observe. The implementation of due diligence obligations in the context of the seabed falls to the 'sponsor' state in the monitoring and regulation of public and private operators that explore and exploit the seabed.

ITLOS Advisory Opinion 17 clarified some aspects related to the responsibility of the sponsor state in these situations. The Tribunal deemed that the state had the obligation to create norms and regulations to guarantee that the contracting company followed a minimum set of environmental norms. Among the preventive measures that should be included in this minimum set of norms are first, the requirement for environmental impact assessments (EIAs) ${ }^{106}$ and secondly, laws that

103 For commercial research and prospecting.

104 International Seabed Authority. Status of Contracts for Exploration in the Area. Twenty-First Session Official Documents (ISBA/21/C/8, 2 June 2015).

105 Direct obligations of States include obligations set out in the Regulations drawn up by the Seabed Authority and obligations under UNCLOS; the Polymetallic Nodules regulation and Polymetallic Sulphide of Regulation, 2010. On this, see International Seabed Authority. Decision of the Assembly of the International Seabed Authority relating to regulations on prospecting and exploration for polymetallic sulphides in the Area (ISBA/16/A/12/Rev.1, Sixteenth Season Official Documents, 2010). On top of that, another frequently cited regulation is International Seabed Authority. Decision of the Council of the International Seabed Authority relating to amendments to the Regulations on Prospecting and Exploration for Polymetallic Nodules in the Area and related matters (ISBA/19/C/17, Nineteenth Season Official Documents, 2013). Also see Responsibility and obligations of States sponsoring persons and entities in the context of activities in the Area [2011] ITLOS Advisory Opinion no. 17 [121]-[140].

106 See paragraph 148 of the Advisory Opinion, which indicates that the environmental impact assessment should not be understood as a custom in international environmental law. The EIA should be required at the time of consultations and 
guarantee the payment of reparations for any damage caused by failure to comply. ${ }^{107}$ It is not enough to create a contract for exploration with a public or private company; there must be a normative framework in place to hold public and private companies accountable for any damages occurring as a result of exploration. If the company is from another country, the state of origin must also sign the work plan, binding itself to be held accountable for any damages.

In the Advisory Opinion the Tribunal held that the sponsor state could not be held responsible for the acts of its companies as long as it is taking the measures that might be reasonably demanded of it and has proceeded with due diligence. ${ }^{108}$ It can be seen here that one of the greatest challenges is actually holding a state responsible for failure to carry out the obligation of due diligence. These obligations are not as specific as they should be and leave room for an improper assessment of the minimum amount necessary to demonstrate compliance. And if the state demonstrates that it performed due diligence, it will not be held liable for any damages caused by the sponsored company, according to the Advisory Opinion. ${ }^{109}$ This represents a dramatic limitation for environmental conservation because not only obligations of conduct must be considered in order to hold the state liable, but also results-based obligations. There are considerable hurdles to be overcome for the content of global public goods management in order for an arbiter to stipulate that a state could be held liable for failure to protect the marine environment.

\section{CONCLUSION}

While the term global 'public good' is neither legal nor operative, it is a useful subject of study as through it we see the lack of precision surrounding the specific obligations of subjects of international law regarding the conservation of marine resources. Global issues require international

notifications pursuant to Art. 142 of UNCLOS. This obligation relates, therefore, to the domestic law of states.

107 See Gabriela Garcia B Lima, 'Caso do Parecer consultivo do Tribunal Internacional de Direito do Mar de $1^{\circ}$ de fevereiro de 2011' in Nitish Monebhurrun, Decisões da corte internacional de justiça e do tribunal internacional sobre o direito do mar (2014) 12 RDI 2, 20, 26.

108 Responsibility and obligations of States sponsoring persons and entities in the context of activities in the Area [2011] ITLOS Advisory Opinion no. 17 [213]-[217].

109 Responsibility and obligations of States sponsoring persons and entities in the context of activities in the Area [2011] ITLOS Advisory Opinion no. 17 [204]. 
and national responses but few international obligations require states to provide and implement these responses. We should ask whether the categories or instruments of international law, consolidated in the law of the sea and environmental law, are capable of ensuring the proper conservation of marine resources. Some aspects are clear in this analysis: first, the interpretive value of the global public good; secondly, the limited content of the global commons and common heritage of mankind regimes for the conservation of marine resources; and third, the need for greater accuracy in the content of obligations to cooperate and obligations of due diligence as applied both nationally and internationally.

The 'global public good' concept currently has no legal grounds and there is no evidence that it will acquire these soon. The relevance and the applicability of the concept, concerning the conservation of marine resources, and more broadly of marine biodiversity, are of an interpretative nature. The cooperation-related content of the global public good is the central aspect that should guide the management of these resources. The nearest legal categories are the global commons and the common heritage of mankind; however, both of these concepts are more closely connected to the internationalization and non-exclusivity of use than to management, which distances them from the implementation of the obligation to cooperate and abide by the principle of prevention in international law. In addition to the cooperation-related content, the global public good concept can uphold the focus on the ecosystem approach of marine biodiversity management. As an interpretative instrument, it can endorse that international environmental law obligations must consider the whole ecosystem instead of a unique specie or a single sector or economic activity. In this sense, the global commons approach could include fisheries as part of the marine biodiversity resources conservation obligations. This interpretation could even, if applied in practice, revitalize fisheries conservation.

Both the obligation to cooperate and the obligation of due diligence, while consolidated in international law, have imprecise content as regards the conservation of marine resources and biodiversity. As living and non-living resources are present in areas under national and international jurisdiction, states' obligations in both spheres must be more precise and detailed to make them actionable and enforceable before national and international courts.

The challenge therefore lies in making existing legal regimes, such as global commons or common heritage of mankind, more precise and more closely connected to obligations related to the conservation of marine resources content. If it is not possible to broaden its interpretation, the concept of 'global public good' could be useful to guide states 
in the implementation of specific measures to conserve marine resources under their jurisdiction, as in the EEZ. The cooperation and due diligence obligations have been enforced for fishing, as was observed in the 21st Advisory Opinion of ITLOS. Other activities, including navigation and exploration of seabed resources, still require greater precision in specific obligations regarding the conservation of marine resources.

Accordingly, the global public goods concept could enlarge and stretch the obligations for the conservation of marine resources, particularly for fisheries. A broadened consequence is to clarify the relevance of considering the ecosystem approach for the governance of marine biodiversity, which has not yet been properly enforced by international environmental law. Some incipient obligations have been drafted in this sense: consideration of the marine environment as a complex functional unit; use of adapted instruments such as integrated management based on the best technology available; ${ }^{110}$ proper compensation; ${ }^{111}$ and an appropriate interpretation of the precautionary approach. ${ }^{112}$

110 Secretariat of the Convention on Biological Diversity, 'The Ecosystem Approach: CBD Guidelines' (2004) 6.

111 Lima, supra n 53, 54.

112 Marr, supra n 39; Cudennec, supra n 54. Jaeckel, supra n 54. 